\title{
Intrinsic and extrinsic factors in preimplantation development
}

\author{
Martin H. Johnson
}

Department of Anatomy, University of Cambridge, Downing Street, Cambridge CB2 3DY, U.K.

The development of the newly fertilized mouse ovum to an implanting blastocyst involves two distinctive types of process. A proliferative process increases cell numbers to approximately 120 and differentiative processes generate phenotypic diversity amongst these genotypically identical cells. The term 'differentiation' has been used to describe a range of phenomena but here it is used in its literal sense. If a cell within an embryo may be distinguished consistently either from its neighbours or from cells in its own lineage then the process of differentiation has occurred. Recognition of the differentiative process will therefore depend on the sensitivity of the methods applied to discriminate between cells. Reliable criteria at biochemical, structural and physiological levels have been used in the past. To these three conventional criteria we would add a fourth criterion-that of cell 'behaviour' (Johnson, Handyside \& Braude, 1977). Such a criterion describes the range of a cell's potential to develop in different ways when experimentally transplanted and amounts to a description of its progressive loss of pluripotentiality. The expression 'behavioural criterion' is used deliberately. Terms such as the process of 'determination', cellular 'decision making' and embryonic cell 'commitment' imply a cellular psychology, the mechanics of which are presently quite obscure. It is perhaps this obscurity that has led to the postulation of a 'determinative process' as a unique, distinctive and quantal event set apart from differentiation as such. With developmental systems, exemplified by Drosophila, in which the putative 'determinative process' appears temporally quite separate from its supposed differentiative consequences, it was perhaps reasonable to impart a special and qualitatively distinctive nature to the process itself. However, for the mouse embryo it seems possible that each restriction on developmental potential may arise progressively, forming part of the differentiation process itself as do molecular and cellular changes, and is not necessarily in itself causal of differentiation (Johnson et al., 1977; Handyside \& Johnson, 1978; Handyside, 1978). Thus experimental assessment of the ease with which the differentiation of an embryonic cell may be reversed provides another feature by which to describe the cell, and therefore to differentiate it from other cells.

Applying these four criteria to the preimplantation mouse embryo at least two distinctive differentiative events have occurred by the stage of the $3 \frac{1}{2}$-day blastocyst. Approximately $53 \mathrm{~h}$ after fertilization at the 8-cell stage, blastomeres undergo the process of 'compaction'. This process is marked by two distinctive morphological features. First, the cell shape changes from spherical to columnar-like. Microtubules become aligned along the long axes of the cells, microvilli are displaced from the sides and bases of the cells and internal organelles are rearranged (Ducibella, 1977). In this way, each cell gains polarity. Second, the columnar cells arrange themselves in a defined spatial relationship to each other, the microvillous-free bases projecting inwards to the centre of the cell cluster, and the apices projecting outwards and forming focal tight junctions with their neighbours. Thus, the individual polarity of each cell becomes organized in a 'tissue' which is rather like an epithelial sphere surrounding a virtual cavity. Non-morphological criteria of differentiation have been applied less systematically to the process of compaction. Differences in the synthesis and turnover of choline-containing lipids and of the enzymes that regulate them occur over the period of compaction (Pratt, 1978). Changes in transport mechanisms, surface sugars and antigenic and protein synthetic profiles have been 
reported to occur around the time of compaction, but it is not clear that the process of compaction itself marks a decisive boundary with regard to any of these changes. There is at present no evidence that the pluripotentiality of the individual cells changes with compaction, but it is not clear whether all the cells of immediate post-compaction morulae are capable of yielding both inner cell mass or trophectoderm (see later: also Johnson et al., 1977, for further discussion). It is, however, established that at least some of the cells can yield both tissues (Handyside, 1978).

The second clearly definable differentiative event to occur in preimplantation development is the foundation of the inner cell mass and trophectoderm cell lineages. Unlike the purely temporal differentiation at compaction, this divergence of cell lines involves both spatial and temporal coordinates. By $3 \frac{1}{2}$ days, the two cell types are differentiated clearly by all four criteria as summarized in Table 1.

Table 1. Criteria for differentiating inner cell mass from trophectoderm in the $3 \frac{1}{2}$ day mouse blastocyst

\begin{tabular}{|c|c|c|}
\hline & Inner cell mass & Trophectoderm \\
\hline Structural & $\begin{array}{l}\text { Focal gap junctions, no desmosomes } \\
\text { Distinctive mitochondria } \\
\text { Few microvilli }\end{array}$ & $\begin{array}{l}\text { Cellular polarity, zonular tight junctions and } \\
\text { desmosomes } \\
\text { Distinctive mitochondria and cytoplasmic } \\
\text { inclusions }\end{array}$ \\
\hline Physiological & $\begin{array}{l}\text { Adherent surfaces, stimulate trophectodermal } \\
\text { proliferation, sensitive to cytotoxic drugs and } \\
\text { high temperature }\end{array}$ & $\begin{array}{l}\text { Phagocytic, transport ions and macromolecules, } \\
\text { secrete fluid, induce decidual response }\end{array}$ \\
\hline Biochemical & Distinctive polypeptides, antigens and enzymes & Distinctive polypeptides, antigens and enzymes \\
\hline Behavioural & $\begin{array}{l}\text { Forms all endoderm, mesoderm and embryonic } \\
\text { ectoderm }\end{array}$ & $\begin{array}{l}\text { Forms primary and secondary trophoblastic } \\
\text { giant cells, ectoplacental cone, extraembryonic } \\
\text { (chorionic) ectoderm }\end{array}$ \\
\hline
\end{tabular}

Data taken from Gardner (1972), Graham (1973), Snow (1973), Ducibella (1977), Izquierdo (1977), Johnson et al. (1977) and Van Blerkom, Chavez \& Bell (1979).

The description now available to us of the events leading to blastocyst formation is not yet complete, but it is sufficient to permit questions to be posed about potential controlling mechanisms. Three general levels of control may be envisaged: (1) regulation by the maternal environment, (2) regulation by the autonomous cells of the embryo through their own genetic activity, through cytoplasmic information or through a combination of both, and (3) regulation through the social interaction of the cells within the embryo.

It is clear that strategies to interfere with normal embryonic development will depend upon the nature of the control mechanism operative at each embryonic stage.

\section{The maternal environment}

There is no convincing evidence to suggest that the maternal environment in which the preimplantation embryo develops is anything other than permissive. Whilst it is not possible to dismiss totally the possibility that highly specific molecules mediate, for example, important changes in the trophectodermal cell surface before implantation, a substantial body of evidence exists to suggest that the female genital tract operates merely to permit or retard an intrinsic programme of development already entrained within the embryo. Thus, blastocysts may form (Biggers, Whitten \& Whittingham, 1971) and implant (Jenkinson, 1977; Sherman et al., 1979) in vitro or in ectopic sites. Asynchrony between embryo and uterus may result in arrest or death but not in abnormality of embryonic organization (Adams, 1979). Exhaustive studies on uterine secretions from several species have not confirmed the existence of specific embryonic regulators, but have revealed an abundance of nutritive substrates, cofactors or substrateligands, for example, retinol (Bazer, Roberts \& Thatcher, 1978), sterols (Cowan, Manes \& 
Hagerman, 1976; Fowler, Johnson, Walters \& Eager, 1977; Pratt, 1978), and ions (Daniel, 1976; Bazer et al., 1978). Even embryos in delay are under a uterine control that appears primarily if not solely to be due to deprivation of key metabolic substrates or cofactors that regulate the rate at which existing endogenous programmes advance, rather than fundamentally diverting embryos along a distinctive path (Van Blerkom et al., 1979).

These observations combine to suggest that the mammalian embryo controls its own developmental course if permitted environmentally to do so. This is not unexpected, of course, in light of the mammal's non-viviparous ancestry.

\section{Cell-autonomous regulation of preimplantation development}

Cellular regulation in differentiating tissues is simplistically but conveniently divided into transcriptional and post-transcriptional levels. Applied to the preimplantation embryo, this division may be equated with the question: is it the embryonic genome or non-genetic stored information that regulates early developmental events?

In answer to this question, a distinctive difference from non-mammalian embryos seems at first to apply. Although the embryonic genome may be active shortly after fertilization of amphibian and echinoderm eggs, development will continue until advanced stages in the absence of transcription of the embryonic genome. However, the apparently irrelevant genetic activity which does occur up to blastulation is in fact essential for the subsequent events of gastrulation and normal differentiation (Brachet, Ficq \& Tencer, 1963; Denny \& Tyler, 1964; Smith \& Ecker, 1965; Barros, Hand \& Monroy, 1966; Giudice, Mutolo \& Donatut, 1968). These sets of observations have led to the conclusion that amphibian and echinoderm embryos use post-transcriptional information to regulate developmental processes - in the earliest phases of development this information is presumably derived from genetic activity in the gametes and inherited via the gametic cytoplasm, and in later phases from the prior synthetic activity of the early embryonic genome. Is there evidence that a similar situation may occur in the mammal?

\section{Precompaction cleaving embryos}

Information specifically derived from the spermatozoon is apparently not essential for development beyond the implantation period (Kaufman, Barton \& Surani, 1977). However, a number of lines of evidence combine to suggest that the egg may provide post-transcriptional information critical to early embryonic development. First, maturation in vitro of the oocytes of mice (Cross \& Brinster, 1970), rabbits (Thibault \& Gérard, 1973), sheep (Moor \& Trounson, 1977; Warnes, Moor \& Johnson, 1977), and several other species (Edwards, 1965) under conditions which permit nuclear maturation but not normal cytoplasmic maturation does not result in viable preimplantation embryos. In contrast, in-vitro conditions which yield relatively normal cytoplasmic differentiation produce eggs which give viable embryos (Warnes et al., 1977; Van Blerkom \& McGaughey, 1978). Second, breeding data from the DDK strain of mice suggest that the females may express a recessive gene during oogenesis, the product of which interacts with the wild-type gene (or gene product) contributed by the male to produce lethality in preimplantation developmental stages (Wakasugi, 1976). Third, Monk (1978) has performed some elegant experiments, most simply explained on the basis of maternally inherited nongenetic information. Using sensitive techniques to assay individual embryos for both an X-linked and an autosomal enzyme, she showed that 8-cell embryos had a unimodal distribution of $\mathrm{X}$ linked to autosomal enzyme activity ratios. Since 8-cell embryos derived from XO mothers also showed a unimodal distribution of ratios but at only half the level of 8-cell embryos derived from $\mathrm{XX}$ mothers, it was suggested that the observed X-linked activity derived from the activity of the $X$ chromosomes in the maturing oocyte (Ohno, Kaplan \& Kinosita, 1961; Ohno, Klinger \& Atkin, 1962; Gartler et al., 1972). At the morula stage, embryos showed a bimodal distribution of enzyme activity ratios, the presumptive $\mathrm{XX}$ females having a double dose of the $\mathrm{X}$-linked 
enzyme while the XY embryos had only one dose. By the blastocyst stage $\mathrm{X}$ inactivation was presumed to have occurred in at least trophectodermal cells, and a unimodal activity ratio was restored. Finally, gross aneuploidy in early embryos is remarkably compatible with early preimplantation development, evidence arguing for a complete independence from genetic control over this developmental period (Kaufman, 1976).

These four observations suggest that cytoplasmic, or at least non-genetic, factors produced during oogenesis may be active after fertilization. They do not, however, indicate at what level the factors might operate. Three sorts of study bear on this question. Bachvarova (1974) has analysed the distribution of radio-labelled RNA in newly ovulated eggs derived from oocytes grown in the presence of labelled precursor. Whilst the bulk of the incorporated label was in transfer (tRNA) and ribosomal (rRNA) RNA, 10-15\% of the total incorporation was in heterogeneous RNA (hnRNA), the presumed precursor of mRNA. This observation serves at least as a basis for carry-over of oocyte mRNA to the zygote. Levey, Stull \& Brinster (1978) have demonstrated that the total quantity of polyadenylic acid does not appreciably alter with fertilization, again suggesting carry-over of maternal mRNA. Schultz (1975) had previously shown that a similar situation existed in the rabbit zygote and moreover had demonstrated that the mRNA was associated with ribosomes.

Several workers have attempted to detect synthesis of hnRNA or mRNA in early mouse embryos. The earliest stage at which this has been successfully demonstrated is the 2-cell mouse embryo (Levey et al., 1978). Similarly RNA polymerase II activity was not detected in 1-cell zygotes, although activity was detected in the polar body nucleus. Only at the 2-cell stage was the enzyme activity found in blastomere nuclei (Moore, 1975).

A third approach more directly suggests that preformed, and perhaps maternally derived, mRNA may be active after fertilization. A number of experiments with the inhibitor of RNA transcription, actinomycin $\mathrm{D}$, have demonstrated that early cleavage shows partial resistance to the drug, and that protein synthetic levels are suppressed by only 50\% (Monesi \& Molinaro, 1970; Tasca \& Hillman, 1970; Golbus, Calarco \& Epstein, 1973). These observations suggest that in the mammal, unlike amphibians and sea-urchins, some but not all of the protein synthesis of early embryos is dependent on new mRNA. However, a role for preformed mRNA is also indicated.

Actinomycin D has several side-effects and is not a specific blocker of mRNA synthesis (Honig \& Rabinovitz, 1965; Laszlo, Miller, McCartney \& Hochstein, 1966; Singer \& Penman, 1972). A more specific inhibitor of RNA polymerase II in vitro is $\alpha$-amanitin (Lindel et al., 1970; Sekeris \& Schmid, 1972; Tata, Hamilton \& Shields, 1972). At doses below $100 \mu \mathrm{g} / \mathrm{ml}$ in vitro the activities of RNA polymerase I and III are not directly affected (Weinmann \& Roeder, 1974) although indirectly secondary inhibition of these enzymes does appear to occur after prolonged incubations of intact embryos in $\alpha$-amanitin (Levey \& Brinster, 1978). $\alpha$-Amanitin has been used on cleaving mouse and rabbit embryos (Golbus et al., 1973; Warner \& Versteegh, 1974; Warner \& Hearn, 1977a; Van Blerkom, 1977; Levey, Troike \& Brinster, 1977; R. A. Taylor \& P. R. Braude, personal communication). In the continuing presence of the drug, the embryos generally undergo at least one round of cleavage before becoming arrested.

When the effect of the drug on incorporation of labelled amino acid into protein is measured, no effect is observed until embryos are approximately $68 \mathrm{~h}$ old, i.e. at about the 20 cell postcompaction stage at which point in normal development a marked quantitative increase in protein synthesis occurs (Johnson et al., 1977; Braude, 1978; R. A. Taylor \& P. R. Braude, personal communication). The absence of an effect before this is not due to a failure of the drug to penetrate into earlier stage embryos, since a 6-h pulse of $\alpha$-amanitin form 3 to $9 \mathrm{~h}$ after fertilization results in arrest at the 2 -cell stage (P. R. Braude \& $R$. Lobatto, personal communication). These results suggest that most of the embryonic protein synthesis before the 68 -h surge is not susceptible to $\alpha$-amanitin inhibition. This is all the more remarkable since it is over the earlier part of this period that most of the major qualitative changes in protein synthetic activity occur (Van Blerkom \& Brockway, 1975). In preliminary studies, on mouse and rabbit 
one-cell embryos developing in vitro, it has been reported that some of these new species of protein continue to appear even in the presence of $\alpha$-amanitin (P. R. Braude \& R. Lobatto, personal communication; J. Van Blerkom, personal communication). Moreover Van Blerkom has suggested that even unfertilized, non-activated rabbit oocytes aged in vivo or in vitro show a part of the sequence of early protein changes contemporary with that observed in fertilized eggs.

Although these findings for early cleavage embryos are still very preliminary, they are consistent with a role for maternally inherited mRNA. The $\alpha$-amanitin studies, with all the difficulties of interpretation that they bring (Braude, 1978), do strongly indicate that stable mRNA is an important template for protein synthesis during early cleavage, and since there is no evidence for a burst of mRNA synthesis immediately after fertilization, much of the stable mRNA may be maternally derived. In this regard, the mouse and rabbit may turn out to be remarkably similar to the frog. Although the frog can achieve post-blastula stages in the presence of transcriptional inhibitors, in the same absolute time of about $10 \mathrm{~h}$ a mouse egg will not even have undergone 1 cleavage. Paradoxically, the mouse may prove to be dependent for a longer absolute time on non-genetic information than the prototypic amphibian.

\section{Blastocyst formation}

Blastocyst formation is distinguished from cleavage stages in several ways. First, a major net quantitative increase in incorporation of precursor into RNA and protein occurs (Brinster, 1971), and appropriate consideration of internal pool size and specific activity suggests that this reflects a real quantitative increase in net protein synthesis (Brinster, Wiebold \& Brunner, 1976). Second, whilst qualitative changes in protein synthesis occur (Handyside \& Johnson, 1978), they are not a major feature of this increased total synthetic activity. It therefore appears that, by and large, the same species of polypeptide are being made at faster rates (Van Blerkom \& Brockway, 1975; Braude, 1978). Third, cytodifferentiation becomes evident over this 24 -h period from compaction to full expansion.

There is no good evidence that information inherited cytoplasmically from the gametes influences the formation of the blastocyst directly. Indeed, there is evidence to favour a rather tight coupling of transcriptional activity to developmental events. The embryonic genome is active before blastocyst formation, as judged by studies on mRNA synthesis (Warner \& Hearn, $1977 \mathrm{~b}$; Levey et al., 1978), and the product of this activity is expressed in the form of recognizable translational products from at least the 6- to 8-cell stage onwards (Wudl \& Chapman, 1976; Muggleton-Harris \& Johnson, 1976).

Studies with $\alpha$-amanitin suggest that, unlike the earliest cleavage events, blastocyst formation is rather more sensitive to interruption of protein synthesis at both molecular and cellular levels. The drug blocks the accelerated rate of protein synthesis in the $68 \mathrm{~h}$ post-fertilization embryo, prevents the occurrence of such qualitative protein changes as are normally detectable and blocks overt blastocyst formation (Johnson et al., 1977; Braude, 1978; and unpublished data). Moreover, the drug is active very rapidly in this regard. If applied within 5-10 h of the expected time of change in these three parameters, the changes are blocked (P. R. Braude, unpublished). This result argues for a rather tight linkage between transcriptional activity and key embryonic events.

\section{Conclusions}

The data presented above suggest a trend in the nature of the developmental control mechanisms operative in the preimplantation development. The very earliest stages are characterized by an important element of post-transcriptional control, whilst by the morula stage, control appears to have shifted primarily to a transcriptional level. There are three implications from these conclusions.

First, strategies for contraceptive attack aimed directly at aborting early cleavage stage embryos might best be directed towards oocyte maturation, rather than towards the embryo itself. 
Second, the point in development at which individual cells commence their differentiation along the distinctive pathway of either ICM or trophectoderm will determine whether maternally inherited post-transcriptional information or selective gene expression is likely to be involved in the underlying control mechanism. This problem is discussed further in the next section.

Third, there is an apparent paradox in the observations that qualitative changes in protein synthesis observed over the period of first cleavage coincide with a period of post-transcriptional control. There are four categories of explanation which might resolve such a paradox.

Messenger RNA could be stored in the oocyte in a 'masked' form, unavailable for translation. The storage could not be random, in view of the requirement for new species of polypeptide. Thus, it would be necessary to postulate distinctive classes of mRNA which could be recognized and sequestered from the protein synthetic machinery of the cell. Such a sequestration could be envisaged as occurring in a number of ways. For example, it has been reported that the proportion of mRNA molecules bearing a guanosine-cap increased after fertilization of the mouse egg and such an event could lead to increased availability for translation in situ (Young, 1977). In the sea-urchin, mRNA associated with ribonuclear protein particles (RNPs) will not translate in vitro unless the protein is first removed, and this apparent inhibitory effect of protein may represent an in-situ control mechanism (Jenkins, Kaumeyer, Young \& Raff, 1978). Also in the sea-urchin, a burst of polyadenylation of pre-existent mRNA occurs at fertilization (Wilt, 1977), but the same does not appear to occur in the mouse (Levey et al., 1978). It must be admitted, however, that none of these mechanisms has been proven to provide, in situ, selective sequestration of $\mathrm{mRNAs}$ coding for distinct individual proteins. Moreover, it is not clear that any mechanism exists for selective treatment of mRNAs according to the proteins which they specify (Lodish, 1976).

A second explanation would not require selective recognition and sequestration of mRNAs as such, but rather a non-specific recruitment of mRNAs due to increased translation efficiency. Since not all mRNAs initiate translation with equal efficiency, a stimulation of overall protein synthetic activity would result in relatively greater synthesis of those proteins coded by less efficient messages. Whilst the relative balance of synthesis of different proteins could be affected by such a mechanism (Lodish, 1976), it is not clear that wholesale qualitative changes of the kind seen in the early embryo would be possible. It is important to note, however, the large store of ribosomes (75\%) unavailable for use in translation in the unfertilized oocyte (Bachvarova \& De Leon, 1977) and which may be made available after fertilization, thus recruiting lower affinity mRNAs. In the rabbit, there is some evidence to suggest that this may occur since the proportion of ribosomes in polysomes increases (Schultz, 1975). However, the absence of any detectable net increase in synthesis of protein after fertilization argues against this notion unless an increase in degradation is also postulated.

A third explanation could rely on the activation of a distinctive type of transcriptional process that was insensitive to $\alpha$-amanitin. Intracisternal A-type particles become visible in 2 -cell mouse embryos, and their appearance is not sensitive to $\alpha$-amanitin (Calarco, 1975). It is possible that the generation of some new polypeptides over this period relates to A-type particle production.

Finally, the role of post-translational modification of pre-existing proteins by digestion or chemical modification would give a change in protein profile with no requirement for transcriptional involvement, and evidence that this occurs for some species of embryonic proteins has been reported (J. Van Blerkom, personal communication). Such events would be recognizable in situ in pulse-chase experiments followed by qualitative analysis. Remarkably little work has been done along these lines which might also reveal the existence of selective degradation of some polypeptides. Such a phenomenon could lead to the erroneous conclusion that selective cessation of synthesis of polypeptides was operating.

There is then an array of mechanisms available to explain transcriptionally independent changes in polypeptide profile during first cleavage. All of them do rely, however, on a stability of 
mRNA of at least $24 \mathrm{~h}$. That this is possible at least for later stage embryos has been demonstrated by Braude (1978).

\section{Social interaction of embryonic cells}

Whilst the clearly differentiated cell lineages of ICM and trophectoderm do not become apparent until $3 \frac{1}{2}$ days, the cellular decisions underlying this divergence could be taken as early as the 1-cell zygote. In principle, if cytoplasmic segregation of post-transcriptional information occurred, then, during cleavage, blastomeres of equivalent nuclear but distinctive cytoplasmic structure would be generated. The cytoplasmic segregants could then determine the direction in which each cell differentiated. Early hypotheses of mammalian development were based on such a premise (Dalcq, 1957; Mulnard, 1965). However, Kelly (1977) has assessed experimentally the degree of totipotentiality in individual blastomeres isolated from cleavage stage 4- and 8-cell embryos and has concluded that the results do not give support to a segregant hypothesis of early development. If this conclusion is accepted, the cellular decisions generating ICM and trophectoderm lineages must presumably be taken at some point after compaction and at a time when transcriptionally controlled activity predominates. It is therefore reasonable to expect selective gene expression to be involved. However, if maternally inherited cytoplasmic factors do not selectively direct gene activity, other directive cues must be sought.

Evidence from two types of experiment suggests that the cells of the morula have recognized in some way their position as being inside or outside and that this recognition directs them to differentiate into ICM or trophectodermal cell respectively. Hillman, Sherman \& Graham (1972) combined genetically or physically marked cleavage-stage blastomeres to form aggregation chimaeras in which cells of one marked type were placed primarily on the outside of the aggregate and cells of the other marked type were placed on the inside. The cells placed inside developed appropriately as ICM, those placed outside as trophectoderm. Thus, unless extensive cell death passed unobserved, the developmental fates of the cells had apparently been altered by altering cell position. Tarkowski \& Wroblewska (1967) postulated that if the positional hypothesis were correct, then reduction of morula cell numbers to a level at which no inside cells were present would result in 'blastocysts' comprised exclusively of trophoblast. Their experimental results were interpreted as fulfilling these predictions. It therefore appears reasonable to conclude that the cells of the embryo are equivalent developmentally until at least the 8-cell stage and that at some point thereafter, by a process of social interaction between cells, relative position is recognized and divergent differentiation initiated.

It is not yet known at what stage in development inside and outside position is first recognized, but it would appear to be an event occurring soon after compaction (see Johnson et al., 1977, for discussion). Polypeptide markers, which have been shown to be tissue-specific for ICM or trophectoderm (Van Blerkom, Barton \& Johnson, 1976), are detectable in the early morula and appear to be distributed unequally between cells on a positional basis. Thus, inside cells synthesize ICM and outside cells synthesize trophectodermal polypeptides (Handyside \& Johnson, 1978). Data from other types of experiment also suggest a relatively early differentiation of inside cells from outside by parameters such as radiation sensitivity (Snow, 1973), ultrastructure (Ducibella, 1977), labelling indices (Graham, 1973) and enzymic activity (Izquierdo, 1977).

The early differentiation of inside cells, taken as a population, does not appear to be irreversible since the cells retain until the expanding blastocyst stage the capacity to form trophectoderm. If inside cell clusters (ICs) are isolated immuno- or iono-surgically from morulae or early blastocyst stages and cultured in vitro, they form blastocysts containing both trophectoderm and ICM (Johnson et al., 1977; Handyside, 1978; Surani, Torchiana \& Barton, 1978; Spindle, 1978; Hogan \& Tilly, 1978). Furthermore, on aggregation with morulae, the ICs contribute to both embryonic and trophectodermal components of the conceptus (A. Handyside, 
unpublished). However, the inside cells isolated from the fully expanded blastocyst have lost this capacity whether tested by short-term culture in vitro (Handyside, 1978) or by aggregation chimaera experiments (Rossant, 1975). It is not yet clear whether outside cells differentiate 'symmetrically' with inside cells, only acquiring a committed status late in differentiation or whether their commitment to trophectoderm is part of the early sequence of differentiation.

Thus, the data presently available suggest that the cells of the morula recognize position quite early after compaction and respond by differentiating. However, the recognition may be followed by a few hours of developmental lability before final commitment. Positional cues probably act by a fairly direct elicitation of selective gene action, since ICs from the morula, when isolated and thus exposed to outside conditions, neither form blastocysts nor synthesize all the trophectodermal-specific marker polypeptides when incubated in $\alpha$-amanitin (unpublished data).

Although we have clues as to the level at which embryonic cells may respond to positional information, nothing is known about the nature of the information utilized by the cells of the morula. The analysis of this phenomenon may be resolved into four types of model.

(1) The earliest stage at which the embryo shows evidence of discrimination of inside and outside position is compaction (Johnson et al., 1977). As pointed out earlier, one feature of compaction is the acquisition of polarity by individual cells. Polarization of structure could be accompanied by polarization of developmental information in the cytocortex or cytoplasm. With subsequent division, cells with a predominance of either ICM-type or trophectoderm-type developmental cues would result. The cues could either fix individual cells on a restricted course of development or merely incline them in that direction, and different cells in the embryo may in fact behave differently. The evidence presently available is consistent with such an early recognition of position.

The alternative to a cytoplasmic zoning model for initiating blastocyst generation is a cellular model in which, after division of cells in the 8-cell compacted embryo, some cells are enclosed within the morula and others exposed outside. By the 8-13-cell stage there are already between 1 and 3 functionally inside cells as judged after immunosurgical isolation (A. Handyside, unpublished). How might these cells recognize themselves as inside?

(2) The formation of the apical tight junctions between blastomeres at compaction could lead to establishment of a permeability seal between inside and out. The seal could hinder dissipation of natural gradients, or permit generation of gradients, such that the microenvironment of any cell subsequently trapped internally would be distinctive (Ducibella, 1977). There is evidence that the permeability seal in the early morula is not in fact very effective, permitting rapid access of immunoglobulin and lanthanum tracer to the interior cells (Ducibella, Albertini, Anderson \& Biggers, 1975; McLaren \& Smith, 1977; Handyside, 1978). Only by the 16- to 32-cell stage are the tight junctions complete (Ducibella, 1977) and only with the formation of the blastocoele is access by antibody reduced (Handyside, 1978). Furthermore, transient arrest of compaction, but not of cell division, by reduction of $\mathrm{Ca}^{2+}$ levels results in disruption of the junctional complexes for several hours, but blastocysts with both ICM and trophectoderm still form (Ducibella, 1977; W. J. D. R. Reeve, personal communication). Furthermore, Kemler, Babinet, Eisen \& Jacob (1977) have used an anti-F9 antiserum to prevent compaction and yet blastocysts with ICM and trophectoderm are nonetheless generated. Taken together, these observations do not support the notion that an early perception of position could be based on microenvironmental cues derived from an effective permeability seal.

(3) Cell junctions of a different nature form between adjacent inside cells and between outside and inside cells (Ducibella et al., 1975). In the early morula, maculae adherentes and gap junctions, but not tight junctions, are present between adjacent inside cells. Gap junctions also develop between inside and outside cells in the 8- to 16-cell morula, at the time that the differentiative properties may be detected, whereas extensive gap junctional complexes only form between adjacent outside or trophectodermal cells in the late morula or early blastocyst (Ducibella et al., 1975; Ducibella, 1977). Gap junctions are believed to be concerned with intercellular transmission of information (Gilula, 1974), and thus a basis for inside : outside contact is 
available. Is it possible that the nature of the specialized contacts between the different cell populations of the morula provides important directional cues as to position? Indeed, could the inside : outside direction of gap junctional contact be a lingering reflection of the cytoplasmic polarization referred to earlier?

(4) Specialized cell junctions may not be involved at all in the perception of position. Compaction appears to maximize the cell contact throughout the morula, resulting in apposition of adjacent membranes (Ducibella, 1977). Thus, the walls of internal cells will be completely in physical contact with other cells, whereas outside cells will have non-contacted surfaces. By defining experimental conditions compatible with cell division but selectively eliminating specialized junctions for various periods of time, it may prove possible to resolve which of the three cellular models mediates the language of the embryonic cells.

\section{Conclusions}

The embryo appears to function on an entrained programme from the moment of its conception. The initial events in its development may be heavily contingent on maternally derived nongenetic information, but it rapidly seems to acquire the capacity to direct its own development. Whilst the uterus may modulate the rate at which the early embryo develops, intrinsic factors appear to govern the nature of its first steps of differentiation.

Strategies to interfere with fertility by direct assault on the embryos will be affected by these conclusions. Since events in the ovarian oocyte may play a key role in first cleavage, agents directed at modifying oocyte maturation could suppress fertility without affecting ovulation, fertilization or cyclicity. Once cleavage is initiated, however, the embryo takes on its own regulation. Perhaps the most promising target here may be to take advantage of the requirement for recognition of position. Since it is known that ICMs alone cannot implant and that trophectodermal vesicles result in empty implantation chambers (Gardner, 1972), interference with the positional cueing in the embryo could result in infertility. However, it is clear that, both in regard of our present lack of knowledge about the early embryo and of doubts about the wisdom of attempting direct interference with its development, the preimplantation embryo will for some time be better aborted indirectly via the traditional means of providing it with an inhospitable uterus.

I am grateful to Dr Peter Braude, Dr Jonathan Van Blerkom, Alan Handyside and John Reeve for valuable discussion and permission to refer to unpublished data, and to Dr Hester Pratt and Dr Gil Schultz for valuable discussion. The experimental work by P.R.B., A.H.H., W.J.D.R. and M.H.J. was supported by grants to M.H.J. from the Medical Research Council and the Ford Foundation.

\section{References}

Adams, C. (1979) Consequences of accelerated ovum transport, including a re-evaluation of Estes' operation. J. Reprod. Fert. 55, 239-246.

Bachvarova, R. (1974) Incorporation of tritiated adenosine into mouse ovum RNA. Devl Biol. 40, 52-58.

Bachvarova, R. \& De Leon, V. (1977) Stored and polysomal ribosomes of mouse ova. Devl Biol. 58 , 248-254.

Barros, C., Hand, G.J. \& Monroy, A. (1966) Control of gastrulation in the starfish, Asterias forbesii. Expl Cell Res. 43, 167-182.

Bazer, F.W., Roberts, R.M. \& Thatcher, W.W. (1978) Actions of hormones on the uterus and effect on conceptus development. J. Anim. Sci., Suppl. 1 (in press).
Biggers, J.D., Whitten, W.K. \& Whittingham, D.G. (1971) The culture of mouse embryos in vitro. In Methods in Mammalian Embryology, pp. 86-116, Ed. J. C. Daniel, Jr., W. H. Freeman \& Co., San Francisco.

Brachet, J., Ficq, A. \& Tencer, R. (1963) Amino acid incorporation into proteins of nucleate and anucleate fragments of sea urchin eggs: effect of parthenogenetic activation. Expl Cell Res. 32, 168-170.

Braude, P.R. (1979) Control of protein synthesis during blastocyst formation in the mouse. Devl Biol. (in press).

Brinster, R.L. (1971) Uptake and incorporation of amino acids by the preimplantation mouse embryo. $J$. Reprod. Fert. 27, 329-338. 
Brinster, R.L., Wiebold, J.L. \& Brunner, S. (1976) Protein metabolism in preimplantation mouse ova. Devl Biol. 51, 215-224.

Calarco, P.G. (1975) Intracisternal A particle formation and inhibition in preimplantation mouse embryos. Biol. Reprod. 12, 448-454.

Cowan, B.D., Manes, C. \& Hagerman, D.D. (1976) Progesterone concentration in rabbit uterine flushings before implantation. J. Reprod. Fert. 47, 359-361.

Cross, P.C. \& Brinster, R.L. (1970) In vitro development of mouse oocytes. Biol. Reprod. 3, 298-307.

Dalcq, A.M. (1957) Introduction to General Embryology, pp. 103-128. Oxford University Press.

Daniel, J.C., Jr (1976) Blastokinin and analogous proteins. J. Reprod. Fert., Suppl. 25, 71-83.

Denny, P.C. \& Tyler, A. (1964) Activation of protein biosynthesis in non-nucleate fragments of sea urchin eggs. Biochem. Biophys. Res. Commun. 14, 245-249.

Ducibella, T. (1977) Surface changes of the developing trophoblast cell. In Development in Mammals, Vol. 1, pp. 5-30. Ed. M. H. Johnson. North-Holland, Amsterdam.

Ducibella, T., Albertini, D.F., Anderson, E. \& Biggers, J.D. (1975) The preimplantation mammalian embryo: characterisation of intercellular junctions and their appearance during development. Devl Biol. 45, 231-250.

Edwards, R.G. (1965) Maturation in vitro of mouse, sheep, cow, pig, rhesus monkey and human ovarian oocytes. Nature, Lond. 208, 349-351.

Fowler, R.E., Johnson, M.H., Walters, D.E. \& Eager, D.D. (1977) The progesterone content of rabbit uterine flushings. J. Reprod. Fert. 50, 301-308.

Gardner, R.L. (1972) An investigation of inner cell mass and trophoblast tissues following their isolation from the mouse blastocyst. J. Embryol. exp. Morph. 28, 279-312.

Gartler, S.M., Liskay, R.M., Campbell, B.K., Sparks, R. \& Gant, H. (1972) Evidence for two functional Xchromosomes in human oocytes. Cell Differentiation 1, 215-218.

Gilula, N.B. (1974) Junctions between cells. In Cell Communications, pp. 1-29. Ed. R. P. Cox. Wiley \& Sons, New York.

Giudice, G., Mutolo, V. \& Donatut, G. (1968) Gene expression in sea urchin development. Wilhelm Roux Arch. EntwMech. 161, 118-128.

Golbus, M.S., Calarco, P.G. \& Epstein, C.J. (1973) The effect of inhibitors of RNA synthesis ( $\alpha$-amanitin and actinomycin $D$ ) on preimplantation mouse embryogenesis. J. exp. Zool. 186, 207-216.

Graham, C.F. (1973) The cell cycle during mammalian development. In The Cell Cycle in Development and Differentiation, pp. 293-310. Eds M. Balls \& F. S. Billett. Cambridge University Press.

Handyside, A.H. (1978) Time of commitment of inside cells isolated from preimplantation mouse embryos. J. Embryol. exp. Morph. 45, 37-53.

Handyside, A.H. \& Johnson, M.H. (1978) Temporal and spatial patterns of the synthesis of tissue-specific polypeptides in the preimplantation mouse embryo. J. Embryol. exp. Morph. 44, 191-199.

Hillmann, N., Sherman, M.I. \& Graham, C.F. (1972) The effect of spatial arrangement on cell determination during mouse development. J. Embryol. exp. Morph. 28, 263-278.
Hogan, B. \& Tilly, R. (1978) In vitro development of inner cell masses isolated immunosurgically from mouse blastocysts. II. Inner cell masses from $3 \cdot 5$ to 4.0 day p.c. blastocysts. J. Embryol. exp. Morph. 45 , 107-121.

Honig, G.R. \& Rabinovitz, M. (1965) Actinomycin D inhibition of protein synthesis unrelated to effect on template RNA synthesis. Science, N.Y. 149, 15041506.

Izquierdo, L. (1977) Cleavage and differentiation. In Development in Mammals, Vol. 2, pp. 99-118. Ed. M. H. Johnson. North-Holland, Amsterdam.

Jenkins, N.A., Kaumeyer, J.F., Young, E.M. \& Raff, R.A. (1978) A test for masked message: the template activity of messenger ribonucleoprotein particles isolated from sea urchin eggs. Devl Biol. 63, 279298.

Jenkinson, E.J. (1977) The in vitro blastocyst outgrowth system as a model for the analysis of periimplantation development. In Development in Mammals, Vol. 2, pp. 151-172. Ed. M. H. Johnson. North-Holland, Amsterdam.

Johnson, M.H., Handyside, A.H. \& Braude, P.R.B. (1977) Control mechanisms in early mammalian development. In Development in Mammals, Vol. 2 , pp. 67-98. Ed. M. H. Johnson. North-Holland, Amsterdam.

Kaufman, M.H. (1976) The incidence of chromosomally unbalanced gametes in $\mathrm{T}(14 ; 15) 6 \mathrm{Ca}$ heterozygote mice. Genet. Res. 27, 77-84.

Kaufman, M.H., Barton, S.C. \& Surani, M.A.H. (1977) Normal postimplantation development of mouse parthenogenetic embryos to the forelimb bud stage. Nature, Lond. 265, 53-55.

Kelly, S.J. (1977) Studies of the developmental potential of 4 - and 8-cell stage mouse blastomeres. $J$. exp. Zool. 200, 365-376.

Kemler, R., Babinet, C., Eisen, H. \& Jacob, F. (1977) Surface antigen in early differentiation. Proc. natn. Acad. Sci. U.S.A. 74, 4449-4452.

Laszlo, J., Miller, D.S., McCarty, K.S. \& Hochstein, P. (1966) Actinomycin D: inhibition of respiration and glycolysis. Science, N.Y. 151, 1007-1010.

Levey, I.L. \& Brinster, R.L. (1978) Effects of $\alpha$-amanitin on RNA synthesis by mouse embryos in culture. $J$. exp. Zool. 203, 351-360.

Levey, I.L., Troike, D.E. \& Brinster, R.L. (1977) Effects of $\alpha$-amanitin on development of mouse ova in culture. J. Reprod. Fert. 50, 147-150.

Levey, I.L., Stull, G.B. \& Brinster, R.L. (1978) Poly (A) and synthesis of polyadenylated RNA in the preimplantation mouse embryo. Devl Biol. 64, 140 148.

Lindell, T.J., Weinberg, F., Morris, P.W., Roeder, R.G. \& Rutter, W.J. (1970) Specific inhibition of nuclear RNA polymerase II by $\alpha$-amanitin. Science, N.Y. 170, 447-449.

Lodish, H. (1976) Translational control of protein synthesis. A. Rev. Biochem. 45, 39-72.

McLaren, A. \& Smith, R. (1977) Functional test of tight junctions in the mouse blastocyst. Nature, Lond. 267, 351-352.

Monesi, V. \& Molinaro, M. (1970) Macromolecular synthesis and effect of metabolic inhibitors during preimplantation development in the mouse. $A d v$. Biosci. 6, 101-120. 
Monk, M. (1978) Biochemical studies on mammalian Xchromosome activity. In Development in Mammals, Vol. 3, pp. 189-223. Ed. M. H. Johnson. NorthHolland, Amsterdam.

Moor, R.M. \& Trounson, A.O. (1977) Hormonal and follicular factors affecting maturation of sheep oocytes in vitro and their subsequent developmental capacity. J. Reprod. Fert. 49, 101-109.

Moore, G.P.M. (1975) The RNA polymerase activity of the preimplantation mouse embryo. J. Embryol. exp. Morph. 34, 291-298.

Muggleton-Harris, A.L. \& Johnson, M.H. (1976) The nature and distribution of serologically detectable alloantigens on the preimplantation mouse embryo. J. Embryol. exp. Morph. 35, 59-72.

Mulnard, J.G. (1965) Studies of regulation of mouse ova in vitro. In Preimplantation Stages of Pregnancy, pp. 123-138. (Ciba Found. Symp. No. 23) Churchill, London.

Ohno, S., Kaplan, W.D. \& Kinosita, R. (1961) Xchromosome behaviour in germ and somatic cells of Rattus norvegicus. Expl Cell Res. 22, 535-544.

Ohno, S., Klinger, M.P. \& Atkin, N.B. (1972) Human oogenesis. Cytogenetics 1, 42-51.

Pratt, H.P.M. (1978) Lipids and transitions in embryos. In Development in Mammals, Vol. 3, pp. 83-129. Ed. M. H. Johnson. North-Holland, Amsterdam.

Rossant, J. (1975) Investigation of the determinative state of the mouse inner cell mass. I. Aggregation of isolated inner cell masses with morulae. J. Embryol. exp. Morph. 33, 979-990.

Schultz, G.A. (1975) Polyadenylic acid-containing RNA in unfertilized and fertilized eggs of the rabbit. Devl Biol. 44, 270-277.

Sekeris, C.E. \& Schmid, W. (1972) Action of $\alpha$-amanitin in vivo and in vitro. FEBS Letters $27,41-45$.

Sherman, M.I., Shalgi, R., Rizzino, A., Sellens, M.H., Gay, S. \& Gay, R. (1979) Changes in the surface of the mouse blastocyst at implantation. In Maternal Recognition of Pregnancy (Ciba Found. Symp. No. 64). Ed. J. Whelan. Excerpta medica, Amsterdam (in press).

Singer, R.H. \& Penman, S. (1972) Stability of Hela cell RNA in actinomycin. Nature, Lond. 242, 100-102.

Smith, L.D. \& Ecker, R.E. (1965) Protein synthesis in enucleated eggs of Rana pipiens. Science, N.Y. 150, 777-779.

Snow, M.H.L. (1973) The differential effect of $\left[{ }^{3} \mathrm{H}\right]$ thymidine upon two populations of cells in preimplantation mouse embryos. In The Cell Cycle in Development and Differentiation, pp. 311-324. Eds M. Balls \& F. S. Billett. Cambridge University Press.

Spindle, A.I. (1978) Trophoblast regeneration by inner cell masses isolated from cultured mouse embryos. $J$. exp. Zool. 203, 483-489.

Surani, M.A.H., Torchiana, D. \& Barton, S.C. (1978) Isolation and development of the inner cell mass after exposure of mouse embryos to calcium ionophore A23187. J. Embryol. exp. Morph. 45, 237-247.

Tarkowski, A.K. \& Wroblewska, J. (1967) Developmental of blastomeres of mouse eggs isolated at the 4- and 8-cell stage. J. Embryol. exp. Morph. 18, 155180 .
Tasca, R.J. \& Hillman, N. (1970) Effects of actinomycin $\mathrm{D}$ and cycloheximide on RNA and protein synthesis in cleavage stage mouse embryos. Nature, Lond. 225, 1022-1025.

Tata, J.R., Hamilton, M.J. \& Shields, D. (1972) Effects of $\alpha$-amanitin in vivo on RNA polymerase and nuclear RNA synthesis. Nature, New Biol. 238, 161164.

Thibault, C. \& Gérard, M. (1973) Cytoplasmic and nuclear maturation of rabbit oocytes in vitro. Annls Biol. anim. Biochim. Biophys., Suppl. 13, 145-156.

Van Blerkom, J. (1977) Molecular approaches to the study of oocyte maturation and embryonic development. In Immunobiology of Gametes, pp. 187-206. Eds M. Edidin \& M. H. Johnson. Cambridge University Press.

Van Blerkom, J. \& Brockway, G.O. (1975) Qualitative patterns of protein synthesis in the preimplantation mouse embryo. Devl Biol. 44, 148-157.

Van Blerkom, J. \& McGaughey, R.W. (1978) Molecular differentiation of the rabbit ovum. I. During oocyte maturation in vivo and in vitro. Devl Biol. 63, 139150.

Van Blerkom, J., Barton, S.C. \& Johnson, M.H. (1976) Molecular differentiation in the preimplantation mouse embryo. Nature, Lond. 259, 319-321.

Van Blerkom, J., Chavez, D.J. \& Bell, H. (1979) Molecular and cellular aspects of facultative delayed implantation in the mouse. In Maternal Recognition of Pregnancy (Ciba Found. Symp. No. 64). Ed. J. Whelan. Excerpta Medica, Amsterdam (in press).

Wakasugi, N. (1974) A genetically determined incompatibility system between spermatozoa and eggs leading to embryonic death in mice. J. Reprod. Fert. 41, 85-96.

Warner, C.M. \& Hearn, T.F. (1977a) The effect of $\alpha$ amanitin on nucleic acid synthesis in preimplantation mouse embryos. Differentiation 7, 89-97.

Warner, C.M. \& Hearn, T.F. (1977b) The synthesis of RNA containing polyadenylic acid sequences in preimplantation mouse embryos. J. Reprod. Fert. 50, 315-317.

Warner, C.M. \& Versteegh, L.R. (1974) In vivo and in vitro effect of $\alpha$-amanitin on preimplantation mouse embryo RNA polymerase. Nature, London 248, 678-680.

Warnes, G.M., Moor, R.M. \& Johnson, M.H. (1977) Changes in protein synthesis during maturation of sheep oocytes in vivo and in vitro. J. Reprod. Fert. 49, 331-335.

Weinmann, R. \& Roeder, R.E. (1974) Role of DNAdependent RNA polymerase III in the transcription of the tRNA and 5sRNA genes. Proc. natn. Acad. Sci. U.S.A. 71, 1790-1794.

Wilt, F.H. (1977) The dynamics of maternal poly(A) containing mRNA in fertilized sea-urchin eggs. Cell ii, 673-681.

Wudl, L. \& Chapman, V. (1976) The expression of $\beta$ glycuronidase during preimplantation development of mouse embryos. Devl Biol. 48, 104-109.

Young, R.J. (1977) Appearance of 7-methylguanosine5'-phosphate in the RNA of mouse 1-cell embryos three hours after fertilization. Biochem. Biophys. Res. Commun. 76, 32-39. 